\title{
Antibacterial Activity of Aqueous Fungal Extracts Derived From Basidiomycetes
}

\author{
Peter Bösiger ${ }^{1}$, Giuseppino Fortunato ${ }^{1 *}$ and Francis WMR Schwarze ${ }^{2,3}$ \\ ${ }^{1}$ Empa, Swiss Federal Laboratories for Materials Science and Technology, Laboratory for Biomimetic Membranes and Textiles, Lerchenfeldstrasse 5, CH- \\ 9014 St. Gallen, Switzerland \\ ${ }^{2}$ University of Freiburg, Faculty of Environment \& Natural Resources, Chair of Forest Botany, Bertoldstrasse 17, DE-79085 Freiburg, Germany
}

${ }^{3}$ Empa, Swiss Federal Laboratories for Materials Science and Technology, Laboratory for Applied Wood Materials, Lerchenfeldstrasse 5, CH-9014 St. Gallen, Switzerland

Submission: November 21, 2017; Published: November 28, 2017

*Corresponding author: Giuseppino Fortunato, Empa, Swiss Federal Laboratories for Materials Science and Technology, Laboratory for Biomimetic Membranes and Textiles, Switzerland, Email: Giuseppino.Fortunato@empa.ch

\section{Commentary}

After the discovery of penicillin, $\beta$-lactam antibiotics with their broad spectrum of action in combination with low toxicity were commonly used as agents for the treatment of bacterial infections. However their frequent abuse and misuse gave rise to increasing numbers of multi resistant bacteria as a result of adaptation [1]. With infectious diseases being one of the most frequent cause of death worldwide the increase in multiresistant bacteria clearly poses threat to global health (WHO, 2014). Researchers, as well as pharmaceutical companies have therefore devoted a lot of effort in the search for new antibacterial substances in the fight against the growing resistance [2,3]. A strategy for the discovery of new promising therapeutic agents is ethno pharmacology, which is "the interdisciplinary scientific exploration of biologically active agents traditionally employed or observed by man" [4]. The potential of ethno pharmacology is highlighted by the fact that for small molecule drugs (excluding peptides, proteins and vaccines) marketed between 1981 and 2010 almost $50 \%$ of them originated or derived from natural products with numbers rising for agents targeting specific diseases such as anticancer drugs (65\%), antibiotics (75\%) or antiviral therapeutics $(77 \%)[5,6]$. New lead substances thereby are not only found in plants but also in other organisms such as fungi which are a source of a vast amount of different metabolites $[7,8]$. Two examples of fungal metabolites that made their way into clinical use are camptothecin [9] as a lead molecule for anticancer drugs and podophyllotoxin [9] for the topical treatment of warts. Mushrooms have been used for their antibacterial, anti-inflammatory and homeostatic properties long before the onset of modern medicine [10-12]. 'Ötzi' the Iceman who lived 3000 BC in the Tyrolean alps, used pharmaceutical active fungi as a prehistoric "first aid kit" $[13,14]$. We therefore screened the crude aqueous fungal extracts of nine basidiomycetes including Fomes fomentarius, Fomitopsis pinicola, Ganoderma adspersum,
Ganoderma lucidum, Ganoderma tsugae, Inonotus obliquus, Laricifomes officinalis, Laetiporus sulphureus and Piptoporus betulinus for their antimicrobial potential. Of the 9 aqueous fungal extracts F. Pinicola and L. officinalis showed a moderate antibacterial activity against the gram positive model organism $S$. arlettae (Figure 1) while growth of gram negative E. coli was not inhibited by any of the extracts. These results are in good agreement with observations made in other studies [15-20] i.e. gram positive bacteria were more susceptible towards fungal extracts than gram negative bacteria such as E. coli. It is however difficult to compare results of bioactivity from different studies as there is no general consensus neither on the antimicrobial assay [21] applied such as well diffusion also known as agar cup method [18], disc diffusion method [20], broth micro-dilution [22], in vivo [23], with which the organisms were tested nor on the production of the fungal extracts and fractions under investigation. Furthermore proper species identification is often neglected [24]. As a result findings in the literature are often discussed in terms of relative trends rather than absolute values. Nevertheless, the poor antibiotic performance demonstrated in this study should not be mistaken for an antimicrobial inefficiency of fungal extracts in general especially taken into account three important considerations. First crude aqueous extracts as applied in this case are always mixtures of active and non-active compounds and as such might be outperformed by their chromatographic fractions $[6,25,26]$ Secondly, water is considered to be a non-solvent for most of the pharmaceutically active constituents including sterols, terpenoids, alkaloids, polyphenols, flavones or lactones commonly found in higher quantities in low polarity organic solvents, while on the other hand it serves almost exclusively as solvent for fungal derived polypeptides and polysaccharides [22,24]. Such substances however, although known for their antimicrobial properties $[19,23,26-28]$, might not reveal their antimicrobial potential in 
diffusion based assays as a result of their high molecular weight $[29,30]$. Thirdly the presence and quantity of pharmaceutically active metabolites in fungi might vary strongly depending on external factors. Various reports have shown the production of metabolites to be substrate dependent [31-34]. In fact the occurrence of certain metabolites might only be observed in the presence of a distinct host [35]. In summary two of the crude aqueous fungal extracts did show a moderate activity against S. arlettae a model organism for gram positive bacteria while none of the extracts tested exhibited an activity against the gram negative E. coli. Nevertheless the antimicrobial potential of basidiomycetes has been demonstrated in countless studies and the reason they did not make their way from naturopathy into clinical practice yet is mostly related to their slow growth rates and low product yields compared to other more proliferative sources such as streptomycetes [15]. Evidence for the pharmaceutical potential inherent to basidiomycetes is the agent pleuromutilin [36,37] a lead substance for a new class of antibiotics nowadays approved for applications in humans and animals.

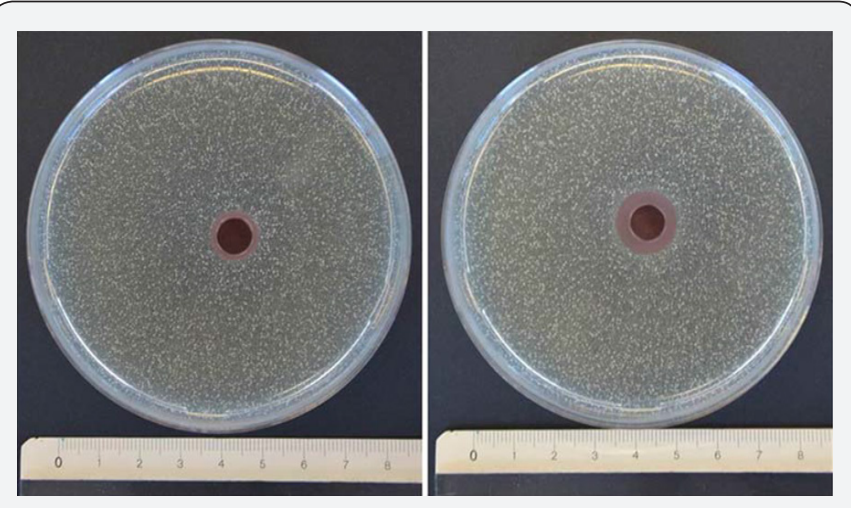

Figure 1: Antibacterial activity against the gram positive $S$. arlettae displayed by aqueous extracts of $F$. pinicola (left) and $L$. officinalis (right) respectively as indicated by the inhibition zones that are highlighted in red.

\section{References}

1. Roth JR (2011) The joys and terrors of fast adaptation: New findings elucidate antibiotic resistance and natural selection. Mol Microbiol 79(2): 279-282.

2. Bilal M, Rasheed T, Iqbal HMN, Hu H, Wang W, et al (2017) Macromolecular agents with antimicrobial potentialities: A drive to combat antimicrobial resistance. Int J Biol Macromol 103: 554-574.

3. de Oliveira JFA, Saito Â, Bido AT, Kobarg J, Stassen HK, et al. (2017) Defeating bacterial resistance and preventing mammalian cells toxicity through rational design of antibiotic-functionalized nanoparticles. Scientific Reports 7(1): 1326.

4. Holmstedt B, Bruhn JG (1983) Ethnopharmacology-A challenge. J Ethnopharmacol 8(5): 251-256.

5. Newman DJ, Cragg GM (2012) Natural products as sources of new drugs over the 30 years. J Nat Prod 75(3): 311-335.

6. Karapanagioti EG, Assimopoulou EN (2016) Naturally occuring wound healing agents: An evidence based review. Curr Med Chem 23(29): 3285-3321.
7. Hoffmeister D, Keller NP (2007) Natural products of filamentous fungi: enzymes, genes, and their regulation. Nat Prod Rep 24(2): 393-416.

8. Cragg GM, Newman DJ (2013) Natural products: A continuing source of novel drug leads. Biochim Biophys Acta 1830(6): 3670-3695.

9. Puri SC, Nazir A, Chawla R, Arora R, Hasan RS, et al. (2006) The endophytic fungus trametes hirsuta as a novel alternative source of podophyllotoxin and related aryl tetralin lignans. J Biotechnol 122(4): 494-510.

10. Molitoris HP (1994) Mushrooms in medicine. Folia Microbiol (Praha) 39(2): 91-98.

11. Molitoris HP (2005) Fungi: Companions of man in good and evil. International Journal of Medicinal Mushrooms 7(1-2): 49-73.

12. Grienke U, Zöll M, Peintner U, Rollinger JM (2014) European medicinal polypores-Amodern view on traditional uses. J Ethnopharmacol 154(3): 564-583.

13. Capasso L (1998) 5300 years ago, the ice man used natural laxatives and antibiotics. Lancet 352(9143): 1864.

14. Peintner R, Pöder U, Pümpel T (1998) The iceman s fungi. Mycol. Res 102(10): 1153-1162.

15. Suay I, Arenal F, Asensio FJ, Basilio A, Cabello MA, et al. (2000) Screening of basidiomycetes for antimicrobial activities. Antonie van Leeuwenhoek 78(2): 129-139.

16. Tsvetkova I, Naydenski H, Petrova A, Kostadinova E, Gyosheva M, et al. (2006) Antibacterial activity of some bulgarian higher basidiomycetes mushrooms. International Journal of Medicinal Mushrooms 8(1): 6366.

17. Turkoglu A, Duru ME, Mercan N, Kivrak I, Gezer K, et al. (2007) Antioxidant and antimicrobial activities of laetiporus sulphureus (Bull.) murrill. Food Chemistry 101(1): 267- 273.

18. Karaman M, Dukic MN, Knezevic P, Svircev Z, Matavuly M, et al. (2009) Antibacterial properties of selected lignicolous mushrooms and fungi from northern serbia. International Journal of Medicinal Mushrooms 11(3): 269-279.

19. Woźniak SK, Szypowski J, Łoś R, Siwulski M, Sobieralski K, et al. (2012) Evaluation of polysaccharides content in fruit bodies and their antimicrobial activity of four ganoderma lucidum (W Curt.: Fr.) P. Karst. strains cultivated on different wood type substrates. Acta Societatis Botanicorum Poloniae 81(1): 17-21.

20. Vazirian M, Faramarzi MA, Ebrahimi SES, Esfahani HRM, Samadi N, et al. (2014) Antimicrobial effect of the lingzhi or reishi medicinal mushroom, ganoderma lucidum (higher basidiomycetes) and its main compounds. Int J Med Mushrooms 16(1): 77-84.

21. Ncube NS, Afolayan AJ, Okoh AI (2008) Assessment techniques of antimicrobial properties of natural compounds of plant origin : current methods and future trends. African Journal of Biotechnology 7(12): 1797-1806.

22. Dresch P, Aguanno DMN, Rosam K, Grienke U, Rollinger JM, et al. (2015) Fungal strain matters: colony growth and bioactivity of the european medicinal polypores fomes fomentarius, fomitopsis pinicola and piptoporus betulinus. AMB Express 5(4): 1-14.

23. Seniuk OF, Gorovoj LF, Beketova GV, Savichuk NO, Rytik PG, et al. (2011) Anti-Infective properties of the melanin-glucan complex obtained from medicinal tinder bracket mushroom, fomes fomentarius (L.:Fr.) Fr.(Aphyllophoromycetideae). Int J Med Mushrooms 13(1): 7-18.

24. Cowan MM (1999) Plant products as antimicrobial agents. Clin Microbiol Rev 12(4): 564-582.

25. Kamra A, Bhatt AB (2012) Evaluation of antimicrobial and antioxidant activity of ganoderma lucidum extracts against human pathogenic bacteria. Journal of Food and Nutrition Research 4(2): 359-362. 
26. Essig A, Hofmann D, Münch D, Gayathri S, Künzler M, et al. (2014) Copsin, a novel peptide-based fungal antibiotic interfering with the peptidoglycan synthesis. J Biol Chem 289(50): 34953-34964.

27. Zhu F, Du B, Bian Z, Xu, B (2015) Beta-Glucans from edible and medicinal mushrooms: Characteristics, physicochemical and biological activities. Journal of Food Composition and Analysis 41: 165-173.

28. Kolundžić M, Grozdanić ND, Dodevska M, Milenković M, Sisto F, et al. (2016) Antibacterial and cytotoxic activities of wild mushroom Fomes fomentarius (L) Fr Polyporaceae. Industrial Crops and Products 79: 110-115.

29. Lewinstein I, Matalon S, Slutzkey S, Weiss EI (2005) Antibacterial properties of aged dental cements evaluated by direct-contact and agar diffusion tests. Journal of Prosthetic Dentistry 93(4): 364-371.

30. Valgas C, Souza MDS, A Smânia EF, Smânia A (2007) Screening methods to determine antibacterial activity of natural products. Braz J Microbiol $38(2)$

31. Jiang L (2011) Comparison of Disk Diffusion, Agar Dilution, and Broth Microdilution for Antimicrobial Susceptibility Testing of Five Chitosans. The Department of Food Science, Graduate Faculty of the
Louisiana State University and Agricultural and Mechanical College.

32. Kahlos K (1994) Inonotus obliquus (chaga fungus): in vitro culture and the production of inotodiol, sterols and other secondary metabolites. Medicinal and Aromatic Plants VI, pp. 179-198.

33. Bai YH, Feng YQ Mao DB, Xu CP (2012) Optimization for betulin production from mycelial culture of inonotus obliquus by orthogonal design and evaluation of its antioxidant activity. Journal of the Taiwan Institute of Chemical Engineers 43(5): 663-669.

34. Sørensen JL, Giese H (2013) Influence of carbohydrates on secondary metabolism in fusarium avenaceum. Toxins (Basel) 5(9): 1655-1663.

35. Zheng W, Liu T, Xiang X, Gu Q (2007) Sterol composition in field grown and cultured mycelia of inonotus obliquus. Yao Xue Xue Bao 42(7): 750-756.

36. Kavanagh F, Hervey A, Robbins WJ (1951) Antibiotic substances from basidiomycetes. VIII. Pleurotus multilus (Fr.) Sacc. and Pleurotus passeckerianus Pilat. Proc Natl Acad Sci USA 37(9): 570-574.

37. Novak RN, Shlaes DM (2010) The pleuromutilin antibiotics: a new class for human use. Curr Opin Investig Drugs 11(2): 182-191.

\section{Your next submission with Juniper Publishers will reach you the below assets}

- Quality Editorial service

- Swift Peer Review

- Reprints availability

- E-prints Service

- Manuscript Podcast for convenient understanding

- Global attainment for your research

- Manuscript accessibility in different formats

( Pdf, E-pub, Full Text, Audio)

- Unceasing customer service

Track the below URL for one-step submission https://juniperpublishers.com/online-submission.php 